\title{
Correction: A behavioral analysis of whistleblowing at Japanese firms
}

\section{Daisuke Asaoka (10)}

Correction to: Humanities and Social Sciences Communications https://doi.org/10.1057/s41599-020-00588-7, published online 16 September 2020

The ninth line of the abstract contained an error. The original text read "wgbhen". The correct text is "when". This has now been corrected in both the PDF and HTML versions of the Article.

Published online: 26 February 2021

(c) Open Access This article is licensed under a Creative Commons Attribution 4.0 International License, which permits use, sharing, adaptation, distribution and reproduction in any medium or format, as long as you give appropriate credit to the original author(s) and the source, provide a link to the Creative Commons license, and indicate if changes were made. The images or other third party material in this article are included in the article's Creative Commons license, unless indicated otherwise in a credit

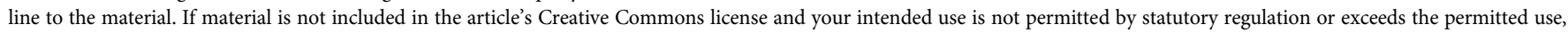
you will need to obtain permission directly from the copyright holder. To view a copy of this license, visit http://creativecommons.org/licenses/by/4.0/.

(C) The Author(s) 2021 